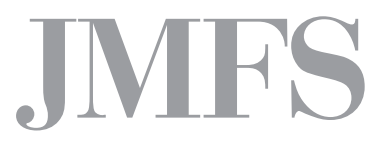

Journal of Management and Financial Sciences
Volume XII

Issue 36 (March 2019)

pp. 31-43

Warsaw School of Economics

Collegium of Management and Finance

Jolanta Maria Ciak

Institute of Finance

WSB in Toruń

\title{
The influence of fiscal rules on the discipline in the public finance in Poland
}

\begin{abstract}
Fiscal rules constitute tools that match the characteristics of a transparent fiscal policy. Increasing the predictability of activities conducted within the public finance sector, which can limit politicians' irresponsible behaviour, is of crucial importance. Fiscal rules may be preventative in nature - they can, therefore, prevent negative phenomena in the area of public finance now and in the near future. They become a kind of obstacle for potential inappropriate fiscal expansion, expenditure expansion in particular, of the public authorities, which could lead to too deep an imbalance between the liabilities of the state and the sources sufficient to cover its obligations. The trends in changes in the current public finance are supplemented by introducing fiscal rules or strengthening their role. The basic problem with fiscal rules is that in many cases they are leaky and are also not consistently observed. The aim of the article is to present a brief overview of national and supranational fiscal rules and reference to the existing situation in the public finance in Poland. The article presents the analysis of the source literature, legal acts and statistical data.
\end{abstract}

Keywords: discipline of public finance, budget deficit, fiscal rules, public debt JEL Classification Codes: H. 61, H. 62 


\section{Introduction}

Discipline is defined as compliance with regulations, principles and rules of procedure which are applicable in a given community or institution, or as a condition which is the result of such compliance, or rigour [Słownik, 1998, p. 212]. Public finance discipline is in turn defined as a particular desired condition whose providing corresponds to compliance with a set of legal standards laid down by the legislator, which concern financial management in the broad sense, and whose breach may result in being prosecuted.

In Polish practice public finance responsibility is identified with responsibility for the breach of public finance discipline [Ustawa, 2004]. As indicated in the source literature, relating the problem of responsibility and discipline to the issues of public finance is significant because the transformations of public finance have led to the occurrence of a few phenomena which can be considered a canon of responsibility [Franek, 2013, p. 98]. A. Premchard defines the phenomena in the following way.

Firstly, fiscal changes in the euro area countries have contributed to the reduction of the governments' credibility and loss of confidence in the public authorities.

Secondly, progressing globalisation made public authorities in many countries oriented towards reacting to appearing threats more than towards an active policy of preventing them.

Thirdly, in many areas of the state activity (e.g. education, health care or social security), financing specific tasks was separated from their providing. It entailed the need to search for mechanisms creating responsibility combining the financial aspect with the efficiency aspect.

Fourthly, the scope of governments' responsibility extended indicating changing tasks and an emphasis on public finance management.

Fifthly, the governments of individual countries transfer their involvement towards creating regulations and gradual reduction of a direct involvement in manufacturing activity [Premchard, 1999, p. 2].

It should be emphasised that the trends in changes in the current public finance are supplemented by introducing fiscal rules or strengthening their role. However, the basic problem with fiscal rules is that in many cases they are leaky and are also not consistently observed.

The main aim of the article is to discuss the fiscal rules functioning on the national and supranational level in the countries of the European Union including Poland and to indicate their role in the development of the government's fiscal situation.

\section{The influence of fiscal rules on the government's fiscal situation: a theoretical approach}

Improving public finance discipline is the main purpose of fiscal rules. According to the definition introduced by G. Kopits and S. Symanski, a fiscal rule is a permanent limitation of 
the fiscal policy reflected in budget indicators of its progress [Kopits, Symanski, 1998, p. 2]. The source literature gives three types of institutional solutions as follows:

- procedural solutions relating to formal rules of preparing and passing the Budget Act, Public Finance Law or other laws and acts;

- solutions relating to the transparency of public finance;

- quantitative solutions that influence the volume of fiscal indicators, i.e. public expenditure, budgetary deficit or public debt [Alesina, Perotti, 1996].

The last of the institutional solutions can be directly associated with fiscal rules.

Both in theory and in practice different classification criteria for fiscal rules are indicated. The criterion of the character of adopted institutional solutions is one of them. On its basis quantitative and qualitative rules are distinguished. The former, called numerical rules, take the form of quantitative limits of selected budget categories [Wójtowicz, 2011, p. 138]. The latter impose limits on the amount of expenditure, taxes, deficit or public debt [Wajda-Lichy, 2006, p. 88]. Another classification of fiscal rules concerns their subject. Rules concerning the general government sector and the local government sector can be distinguished. There are also rules concerning the whole sector of public finance.

The criterion of the breakdown of rules by geographical scope has been gaining in significance in recent years and it results in separating supranational and national rules [Marchewka-Bartkowiak, 2012, p. 48].

It should be emphasised that fiscal rules are becoming tools that match the characteristics of a transparent fiscal policy. First of all, it is important to increase the predictability of activities conducted within the public finance sector, which limits politicians' irresponsible behaviour [Piwowarski, 2011, p. 253]. Therefore, these rules can play a specific role for the state's financial situation, the future policy in particular. Their preventative character is often emphasised, thus, they can prevent negative phenomena in the area of public finance. According to some economists, rules become a kind of obstacle for potential inappropriate fiscal expansion, expenditure expansion in particular, of the public authorities, which could lead to too deep an imbalance between the liabilities of the state and the sources sufficient to cover its obligations. It is emphasised by S. Owsiak, who indicates that the purpose of rules is also to protect the society from disproportionate burdens resulting from the costs of public debt servicing, which constitute the state's unproductive expenditure and a price paid for a constant budgetary imbalance [Owsiak, 2013, p. 7].

In recent years there have been no doubts about the necessity to manage public revenues effectively in order to prevent a waste of public financial resources. Thus, there is a widespread agreement with respect to the concern about the condition of public finance. As M. Postuła indicates, created fiscal rules should allow the implementation of the government's economic programme with a predefined framework ensuring the maintenance of macroeconomic stability [Postuła, 2011, p. 42].

Fiscal rules can influence the changes in a country's financial situation because of the political cycle (changing governments), a specific socio-economic doctrine, an expenditure 
doctrine or a tax doctrine preferred by a given government [Owsiak, 2013, p. 7]. For this reason, introducing fiscal rules is in principle to limit politicians' freedom to influence the fiscal policy.

\section{Fiscal rules binding in the countries of the European Union}

Ensuring macroeconomic stability of a given country was the reasoning underlying the introduction of fiscal rules in the countries of the European Union. However, this was not at all about activities in the sense of automatic stabilisers of the market situation, but about protecting economies from excessive extending of the public sector. As it is indicated in the source literature, countercyclical influence of fiscal rules is possible in practice, which, however, does not constitute a basis for their introduction [Piwowarski, 2011, p. 225].

In recent years the usage of fiscal rules has been intended for conducting a disciplined fiscal policy, which is necessary for achieving sustainable economic development in the longterm perspective.

For instance, the Stability and Growth Pact indicated two supranational numerical rules - regarding the budgetary deficit ratio of $3 \%$ of GDP and the public debt ratio of $60 \%$ of GDP. The provisions of the Pact emphasise the need to respect the criteria through the requirement of achieving sustainability of the budget or budgetary surplus in the public finance sector in the medium term. This results from the fact that the euro area candidate countries undertook actions (within the period of meeting the convergence criteria) aimed at lowering fiscal parameters (Italy, Belgium). The experiences of using the initial version of the Stability and Growth Pact indicated poor effectiveness of the authorities of the Community in implementing clearly formulated recovery procedures (including financial in character penalties). The procedure of imposing penalties on the euro area countries in connection with the existence of an excessive deficit and the lack of effective actions for its limiting remains theoretical [Ciak, 2011a, p. 18].

Research conducted on the functioning and effectiveness of fiscal rules suggests that supranational fiscal rules are not a successful resolution that could discipline activities of fiscal authorities in individual countries. It can result from incorrect understanding of fiscal rules and their role as well as the lack of penalties for their violation. An accompanying system of penalties and duties should constitute a tool for the correct functioning of a specific rule [Postuła, 2011; Piwowarski, 2011; Ciak, 2015; Redo, Wójtowicz, Ciak, 2018].

On the other hand, national fiscal rules should be treated as a complementary tool for obligations imposed by the abovementioned Pact. Fiscal rules on the national level become an element facilitating conducting the fiscal policy in accordance with the most important premises constituting the basis of the reform of the Stability and Growth Pact. The data of the European Commission shows that between 1990 and 2008 the number of fiscal rules rose from 16 to 67 , with the majority of the countries introducing more than one fiscal rule. Only three countries did not introduce any national rules (Cyprus, Greece and Malta). At 
the same time Bulgaria, France, Lithuania, Portugal and Hungary introduced specific fiscal rules [Public Finance, 2009, p. 87].

Moreover, it should be emphasised that since 2000 the application of expenditure rules has been growing dynamically, probably because those rules directly influence the expenditure aspect of the budget, they are transparent and potentially easy to be executed [Działo, 2016, p. 212].

Other solutions, for example those in the area of the budget balance rule, have the character of quantitative limits expressed in nominal terms, as a share of GDP or in structural quantities. One of the constructions used nowadays bases on the structural balance ratio [Owsiak, 2013, p. 14; Moździerz, 2009] ${ }^{1}$, which enables conducting a countercyclical budgetary policy. This rule was introduced in 2005 at the EU level under the reform of the Stability and Growth Pact and then strengthened by another reform of the Pact in 2009. In the light of those changes, a few countries of the European Union have applied also national rules based on this concept [Franek, 2010, p. 71]. Sweden and Germany can be two examples. In Sweden the requirement to achieve a structural surplus of the public sector of $1 \%$ of GDP is in force along with the expenditure rule, whereby in Germany a constitutional provision has been introduced which requires the federal government to maintain the structural balance of a budgetary deficit at the maximum level of $0.35 \%$ of GDP. The rule has been in force since 2016.

The fiscal Pact, which constitutes an international agreement, implies the need to maintain a balanced budget, bigger control of the Council of the European Union and the European Commission over the condition of public finance in the countries and a better coordination of the economic policy. As stated in the Treaty on the Functioning of the European Union, the general government and local government balance must be counterbalanced or manifest a surplus. This condition is met if an annual structural general government and local government balance achieves the medium-term goal for a given country which is specified in the changed Stability and Growth Pact, with the minimum level of $0.5 \%$ of GDP at market prices. Every country ought to ensure fast achievement of the medium-term objective (for Poland it is the level of $-1 \%$ of GDP).

\section{Polish fiscal rules}

The applicable principles of the functioning of fiscal rules are specified in detail by the Act of $27^{\text {th }}$ August 2009 on the Public Finance and the Constitution of the Republic of Poland adopted on $2^{\text {nd }}$ April 1997. Among the existing rules, the following ones are the most important: - constitutional limit on the public debt in Poland at the level of 3/5 of GDP [ the Constitution of Poland of 1997, Art. 216.5];

1 It is worth emphasising that in the source literature the concept of structural balance has started to be criticised, the issues of the accuracy of the evaluation of potential output which constitutes the foundation of the concept in particular. 
- prudence and recovery procedures in the Public Finance Act (at the level of 55\% and 60\% of GDP); [the Act of 2009, Art. 86.1 point 2];

- the rule existing from $1^{\text {st }}$ January 2011 to $31^{\text {st }}$ December 2013 that limited the growth rate of expenditure other than legally determined (and new expenditure legally determined) to the projected inflation rate increased by one percentage point (so called disciplining expenditure rule); [the Act of 2009, Art. 112aa];

- with respect to the local government units the rule of at least sustainable outgoing output and existing from 2014 individual debt ratios [the Act of 2009, Art. 243].

The first of the rules, which is included in Chapter X of the Constitution of the Republic of Poland, implies the prohibition of excessive financial burden on the state in the form of increasing the level of the national public debt over $60 \%$ of GDP ( $3 / 4$ of annual GDP).

Attention can also be drawn to a fiscal rule concerning public debt that can be found in the Act on the Public Finance within the framework of prudence procedures (before 2012 three prudence thresholds functioned: public debt/GDP: 50\%, public debt/GDP: 55\% and public debt/GDP: 60\%; only the last two ones exist nowadays). In 2013 Article 86a was introduced, which repealed the earlier Article 86 paragraph 1 point 1, and it enabled amending the budget act for 2013 when it came to, among others, increasing the amount of the budgetary deficit. The change provokes a type of discomfort because such activities seem to be ad hoc law improvement, searching for temporary and not systemic solutions, which postpone legal solutions by the public authorities, who are obliged by the prudence and recovery procedures of the abovementioned Act [Pomorski, 2014, p. 563]. What is more, during the period of validity of the aforementioned prudence thresholds, provisions concerning exceeding one of the thresholds were mitigated. It was, among others, the requirement to balance the budget, when exceeding the public debt/GDP ratio of $55 \%$ in particular.

It should be emphasised as well that when it comes to the first prudence threshold (public debt/GDP: 50-55\%), first it was excluded from application in 2013, then it stopped being legally binding and finally abolished. The rationale offered for those decisions was the effects of the financial crisis in the euro area, much worse ratios of GDP in particular, as well as the need to mitigate the effects of the economic downturn in Poland in the context of excessive deficit proceedings against Poland in 2009.

The public debt rule, though it concerns the whole public finance sector, provides guidelines in the scope of the fiscal policy only when the public debt-to-GDP ratio exceeds the prudence thresholds. It does not, however, indicate any activities that would help to avoid excessive public debt, although it somehow enforces limiting the public funds imbalance when they are significantly weakened. The provisions concerning crossing the prudence thresholds included in the Public Finance Act are not applied in statutory extreme situations such as martial law, state of emergency or a natural disaster on the whole territory of the Republic of Poland.

The stabilising fiscal rule is a rule that, after exceeding the prudence thresholds, sets the expenditure limit for each year but not only in the case of a public finance imbalance. Unlike the temporary expenditure rule, the new rule concerns almost the whole public finance sector 
(apart from small expenses, small units, which are not legally able to take on high deficits, and expenditure fully financed with EU funds). The purpose of the rule is to ensure the stability of public finance in Poland and correct a possible excessive imbalance, but also to avoid excessive fiscal policy tightening particularly at the time of a significant economic downturn [Redo, Wójtowicz, Ciak, 2018].

It is worth emphasising that before the stabilising fiscal rule entered into force, the need to change and complement the system with an additional mechanism was frequently indicated. The personal scope of the solutions functioning before the end of 2013 was limited - they concerned only a part of the public finance sector. The current rule is of countercyclical character, which means that in good economic times expenditure is to grow more slowly than GDP and faster at the time of economic downturn [Duda, 2014, p. 706]. The public debt rule, in turn, although it concerns the whole public finance sector, provides guidelines in the scope of the fiscal policy only when the public debt-to-GDP ratio exceeds the prudence thresholds. It does not, however, indicate any activities that would help to avoid excessive public debt, although it somehow enforces limiting the public funds imbalance when they are significantly weakened.

The stabilising fiscal rule was introduced in 2014. It is an instrument which should ensure long-term stability of the state's finance in Poland. As mentioned above, the rule includes a countercyclical element. Therefore, in the period when specified stability criteria are not fulfilled, the expenditure amount will grow with the medium-term rate of GDP growth, with the amount of expenditure from the previous year constituting the starting point when establishing expenditure for a given year [Duda, 2014, p. 707]. The abovementioned expenditure rule is used to finish the process of consolidation and then stabilising public finance understood as achieving in the medium term the general government deficit at the level of the medium-term budgetary objective. The stabilising rule functioning should improve public finance discipline. However, evaluating its effectiveness will take at least a few years.

The aforementioned rule thereby combines the national and European framework of the fiscal policy increasing the stability of the budget policy. Unlike the debt rule, it imposes constrains on public finance annually and not only after the threshold is exceeded and it enables conducting a countercyclical fiscal policy. The mechanism that corrects the rules constitutes an element of monitoring the medium-term stability of public finance thanks to taking into account the medium-term budgetary objective.

Attention should be drawn to the problem of the low effectiveness of the EU fiscal rules in disciplining the public finance in the Member States in connection with the lack of their legal basis in laws of the Member States, and most of all the lack of political will in returning to healthy public finance in many of them [Ciak, 2015, p. 260]. It should be noted, however, that in the EU there are also economies which regularly achieve surpluses in their state budgets and/or economies with relatively low public debts (for example Finland, Denmark, Sweden, Bulgaria), and a significant public debt in the majority of instances results from several decades of an overly expansive fiscal policy and not only the recent crisis [Redo, Wójtowicz, Ciak, 2018]. 


\section{Deficit and public debt in Poland: a practical approach}

As it was indicated above, rules concerning deficit and public debt are mentioned both at the national and supranational level. The table below presents the state budget deficit, public finance sector deficit as well as general government deficit ${ }^{2}$ in the years 2000-2016.

Table 1. The state budget deficit, public finance sector deficit and general government deficit in Poland in the years 2000-2016

\begin{tabular}{|c|c|c|c|c|c|}
\hline \multirow[t]{2}{*}{ Specification } & \multicolumn{2}{|c|}{$\begin{array}{l}\text { Budgetary deficit } \\
\text { (state budget deficit) }\end{array}$} & \multicolumn{2}{|c|}{ Public finance sector deficit } & \multirow{2}{*}{$\begin{array}{c}\text { general government } \\
\text { deficit (ESA 2010) } \\
\% \text { GDP }\end{array}$} \\
\hline & PLN billion & $\%$ GDP & PLN billion & $\% \mathrm{GDP}$ & \\
\hline 2000 & -15.4 & -2.1 & -21.5 & -2.9 & -3.0 \\
\hline 2001 & -32.4 & -4.1 & -38.2 & -4.9 & -4.8 \\
\hline 2002 & -39.4 & -4.9 & -46.2 & -5.7 & -4.8 \\
\hline 2003 & -37.0 & -4.4 & -45.3 & -5.4 & -6.1 \\
\hline 2004 & -41.4 & -4.4 & -41.9 & -4.5 & -5.0 \\
\hline 2005 & -28.4 & -2.9 & -29.6 & -3.0 & -4.0 \\
\hline 2006 & -25.1 & -2.3 & -22.2 & -2.1 & -3.6 \\
\hline 2007 & -16.0 & -1.3 & 1.7 & 0.1 & -1.9 \\
\hline 2008 & -24.3 & -1.9 & -20.6 & -1.6 & -3.6 \\
\hline 2009 & -23.8 & -1.7 & -50.1 & -3.7 & -7.3 \\
\hline 2010 & -44.6 & -3.1 & -85.1 & -5.9 & -7.3 \\
\hline 2011 & -25.1 & -1.6 & -56.3 & -3.6 & -4.8 \\
\hline 2012 & -30.4 & -1.9 & -37.6 & -2.3 & -3.7 \\
\hline 2013 & -42.2 & -2.5 & -48.4 & -2.9 & -4.1 \\
\hline 2014 & -29.0 & -1.7 & -39.6 & -2.3 & -3.5 \\
\hline 2015 & -42.6 & -2.4 & -44.0 & -2.4 & -2.6 \\
\hline 2016 & -46.2 & -2.5 & -46.1 & -2.5 & -2.4 \\
\hline
\end{tabular}

Source: M. Redo, K. Wójtowicz, J.M. Ciak (2018). Bezpieczeństwo Finansów Publicznych. Warszawa: CeDeWu.

Permanent public finance deficits in Poland, also in good economic times, decreased the flexibility of the fiscal policy when the crisis started in autumn 2008 and led to historically high deficits of the public finance sector in the years 2009-2011, which exceeded the Treaty level of $3 \%$ of GDP. As a consequence, the excessive deficit procedure was imposed on Poland

2 This distinction between the notions is due to the fact that a few definitions of budgetary deficit and public debt exist in Poland (Table 1 and 2). It results from a parallel application of the EU and national methodology of calculating deficit and debt. The differences between the definitions concern, among others:

- A different approach to the definition (scope) of the public finance sector. In Poland the scope of this sector is specified by the Public Finance Act of $27^{\text {th }}$ August 2009 (article 9), and the EU methodology involves additional functional criteria (such as the structure of the sector financing). It means that the scope of the sector is changeable;

- Debt securities. The differences result from the cash budgetary accounting system used in Poland and accrual accounting in the EU. For instance, so called requested liabilities of the public sector units are treated as public debt according to the Polish definition, whereas in the EU methodology they are not [Lotko, Zawadzka-Pąk, 2016, p. 51]. 
from July 2009 to June 2015. High deficits in Poland existing for 16 years result in the increase in the borrowing needs of the public finance sector, and the sale of treasury securities has amounted PLN 120-200 billion a year. It results in pushing other subjects out of the financial market, limiting the development of other segments of the market and reducing the attractiveness of the Polish financial market and foreign investors' interest in it. It complicates the access to the sources of founding of economic activities in Poland, increases their cost and forces business entities to take out bank loans - from institutions, which in the situation of such high supply of relatively safe treasury bonds with a good interest rate (in the situation of significant borrowing needs of the public finance sector) are not interested in credit activity (at the end of 2016 the national banking sector owned PLN 251 billion worth of treasury bonds, that is $43 \%$ of treasury securities in circulation). Constantly high budgetary deficits cause a dynamic increase in public debt and the increase in annual borrowing needs of the State Treasury.

Table 2. Differences between the level of public debt, general government debt and the State Debt in the years 2000-2016

\begin{tabular}{|c|c|c|c|c|c|c|}
\hline \multirow{2}{*}{ Specification } & \multicolumn{2}{|c|}{ State debt } & \multicolumn{2}{c|}{ Public debt } & \multicolumn{2}{c|}{ General government debt } \\
\cline { 2 - 7 } & PLN billion & \% GDP & PLN billion & \% GDP & PLN billion & \% GDP \\
\hline 2000 & 266.8 & 35.7 & 280.3 & 37.5 & 272.3 & 36.5 \\
\hline 2001 & 283.9 & 36.4 & 302.1 & 38.7 & 291.2 & 37.3 \\
\hline 2002 & 327.9 & 40.5 & 352.4 & 43.5 & 338.7 & 41.8 \\
\hline 2003 & 378.9 & 44.8 & 408.3 & 48.3 & 394.1 & 46.6 \\
\hline 2004 & 402.9 & 43.2 & 431.4 & 46.2 & 420.3 & 45.0 \\
\hline 2005 & 440.2 & 44.7 & 466.6 & 47.1 & 460.0 & 46.4 \\
\hline 2006 & 478.5 & 44.9 & 506.3 & 47.3 & 502.3 & 46.9 \\
\hline 2007 & 501.5 & 42.3 & 527.4 & 44.4 & 524.4 & 44.2 \\
\hline 2008 & 569.9 & 44.6 & 597.8 & 46.5 & 595.4 & 46.3 \\
\hline 2009 & 631.5 & 46.4 & 669.9 & 48.8 & 678.3 & 49.4 \\
\hline 2010 & 701.9 & 48.6 & 747.9 & 51.7 & 767.8 & 53.1 \\
\hline 2011 & 771.1 & 49.2 & 815.3 & 52.0 & 847.7 & 54.1 \\
\hline 2012 & 793.9 & 48.7 & 840.5 & 51.6 & 875.1 & 53.7 \\
\hline 2013 & 838.0 & 50.6 & 882.3 & 53.3 & 922.8 & 55.7 \\
\hline 2014 & 779.9 & 45.4 & 826.8 & 48.1 & 864.0 & 50.2 \\
\hline 2015 & 834.6 & 46.6 & 877.3 & 48.8 & 919.6 & 51.1 \\
\hline 2016 & 928.7 & 50.1 & 965.2 & 52.1 & 1006.3 & 54.4 \\
\hline
\end{tabular}

Source: M. Redo, K. Wójtowicz, J.M. Ciak (2018). Bezpieczeństwo Finansów Publicznych. Warszawa: CeDeWu.

Public debt in Poland in turn does not exceed the Treaty (and at the same time the constitutional) level of debt of $60 \%$ of GDP (Table 2). It should be mentioned here that this criterion is considerably flexibly evaluated, otherwise the euro area would never have been created. In 1998, when it was being estimated whether a country met the conditions to become a member 
of the created euro area, the criterion of public debt was fulfilled by four countries only: Luxemburg, Finland, France and Great Britain [Redo, Wójtowicz, Ciak, 2018]. It was later reflected in the Treaty broadening of the interpretation of the public debt criterion, where it was added that the countries whose public debt-to-GDP ratio was decreasing at a satisfactory pace were also acceptable, unless a country was subject to the excessive deficit procedure.

Taking the data from Table 2 into account, a few issues should be drawn attention to.

Firstly, in 2016 the general government debt slightly exceeded the level of PLN 1 trillion.

Secondly, public debt is currently three and a half times as big as it was at the beginning of the $21^{\text {st }}$ century (in the years 2000-2016 the national public debt grew from PLN 280 billion to PLN 965 billion).

Thirdly, it is also significant that the pubic debt-to-GDP ratio has constantly amounted to $50 \%$ of GDP for fourteen years, though it more than doubled (by 136\%) in the years 2003-2016.

Fourthly, before and in 2008 the public debt exceeded the general government debt, and then a reversal in the relation between the Polish and the EU statistics took place.

The above leads to a conclusion that playing with the statutory scope of the public finance sector, the definition of public debt, the rules of fixing of the exchange rate for conversion, or with differences in bookkeeping of operations and also with the method of GDP calculating constitute ways of manipulating published statistics in the scope of public debt (nominally and in relation to GDP). It does not, however, change the fact that annual significant budgetary deficits in Poland cause a dynamic increase in public debt and despite the fact that official statistics of the debt has remained at the same level of about 50\% of GDP for twelve years, it has been taken into account in required by investors premiums for risky investments for years [Redo, Wójtowicz, Ciak, 2018].

The issues are confirmed by other expert analysts of deficit and public debt, who indicate that Poland has never exceeded the accepted level, even due to the last financial and economic crisis that started in 2007 the debt threshold was not exceeded. The situation is different in the case of the general government deficit. The acceptable level was exceeded ten times in Poland's twelve years' history of the adherence to EU structures. Even the existence of the EU excessive deficit procedure did not prevent Poland from planning or running the general budget deficit above the acceptable threshold.

\section{Summary}

Application of fiscal rules relating to the process of public finance management can be one of the conditions of securing the stability of public finance. Fiscal rules can be thought to be an essential element of conducting a disciplined fiscal policy, but their effectiveness depends on many factors. They are linked with not only the selection of the adequate fiscal aggregate, but also with, among others, their legitimacy, the principles of compliance or enforcement of sanctions for their violation. 
The fiscal rules included in the Maastricht Treaty together with the European Union regulations of recovery character entered in the Stability and Growth Pact have proved ineffective. The ineffectiveness can be explained by the financial crisis, however, difficulties in maintaining public finance discipline appeared in many countries of the EU before the crisis [Ciak, 2011b, p. 75-76].

In the case of Poland, the fiscal rule which concerns public debt and is included in the Constitution of the Republic of Poland of 1997 and prudence procedures included in the Articles 86 and 87 of the Public Finance Act of 2009 can be considered strong ones [Ciak, 2015, p. 260]. However, despite the statutory provision, there are possibilities of partial circumventing it (for instance, by freezing the prudence threshold in 2013).

Another rule is the stabilising fiscal rule, whose functioning should increase the discipline of public finance. A few years are needed before an evaluation of the rule can be conducted. The aforementioned rule combines both the national and European frameworks of the fiscal policy increasing the stability of the budgetary policy as, unlike the debt rule, it imposes limitations on public finance annually and not only after a threshold is crossed and it enables conducting a countercyclical fiscal policy. The rule correction mechanism, by taking into account the medium-term budgetary objective in it, constitutes an element of monitoring of medium-term pubic finance stability.

It is possible to conclude that fiscal rules could become an important and effective factor strengthening the discipline of public finance; however, their correct legitimacy is necessary as it prevents their circumventing with the use of a system of sanctions for their breaking. Widespread awareness of the consequences for the whole economy in connection with deficits in finance and growing public debts as well as accountability to citizens (and next generations) for the conducted fiscal policy are of major importance.

Despite the fact that Poland respects the existing fiscal rules and that international ratings are high, significant levels of budgetary deficits and of public debt should be limited, first of all to minimalize the risk of the necessity of unexpected cuts in expenditure and adjusting the fiscal policy in the future, especially because making sure public finance is stable and thus secure currently constitutes a challenge not only for Poland, but also for the majority of the EU countries. It results from the worsening of fiscal positions and a sharp public debt increase resulting from the financial crisis and negative demographic trends.

The weakness of fiscal rules is the fact that they do not concern the whole public finance sector, but they relate only to its selected elements. This raises the temptation and offers opportunities to manipulate in accounting by, for instance, changing the qualifications of budgetary operations. The less transparent public finance, the greater the tendency to recourse to accounting tricks will be. Even for the best constructed, hiding the scale of real financial commitments of the public finance sector. The effectiveness of fiscal regulations also depends on the clarity and transparency of public finance. In conclusion, the impact of fiscal rules is limited. The governments wishing to conduct a correct fiscal policy will do so notwithstanding the rules functioning in a given country, but those wanting to increase deficit excessively can circumvent them pretty easily. 


\section{References}

\section{Legal acts:}

1. Ustawa z dnia 2 kwietnia 1997 r. Konstytucja Rzeczpospolitej Polskiej, Dz.U. 78, poz 483 z późn. zm. [The Act of April 2, 1997. Constitution of the Republic of Poland, Journal of Laws 78, item 483, as amended].

2. Ustawa $\mathrm{z}$ dnia 17 grudnia 2004 roku o odpowiedzialności za naruszenie dyscypliny finansów publicznych, Dz. U. 2005, nr 14, poz. 114. [Act of December 17, 2004 on liability for violation of public finance discipline, Journal of Laws 2005, No. 14, item 114].

3. Ustawa z dnia 27 sierpnia 2009 r. o finansach publicznych, Dz.U. 2013, poz. 885 i 938. [Act of 27 August 2009 on public finance, Journal of Laws 2013, item 885 and 938].

4. Other publications:

5. Alesina, A., Perotti, R. (1996). Fiscal Discipline and the Budget Process. American Economic Review, Vol. 86, No. 2.

6. Ciak, J. (2011a). Kontrowersje wokół Paktu na rzecz stabilności i wzrostu. Roczniki Naukowe WSB, Toruń, No 10(10).

7. Ciak, J. (2011b). Kryzys finansowy a deficyt sektora finansów publicznych w Polsce i krajach Unii Europejskiej, Ekonomiczne i prawne uwarunkowania i bariery redukcji deficytu i długu publicznego. J. Szołno-Koguc, A. Pomorska (Eds.), Monografie LEX. Warszawa: LEX, Wolter Kluwer.

8. Ciak, J.M. (2015). Fiscal Rules in Polish Law and the European Union. In: Acta Universitatis Brunesis, Iuridica, Editio Scientia, Vol. 514. Retrieved from: https:/www.law.muni.cz/sborniky/ system-of-financial-law/general-part.pdf [accessed: 30.11.2017].

9. Duda, M. (2014). Wieloletni Plan Finansowy Państwa i ustawa budżetowa. In: P. Smoleń (Ed.). Ustawa o finansach publicznych. Komentarz. Warszawa: CH Beck.

10. Działo, J. (2016). Indeks reguł fiskalnych jako miara jakości reguł fiskalnych w Unii Europejskiej. Studia prawno-ekonomiczne, Vol. XCIX.

11. Franek, S. (2013). Kryterium odpowiedzialności jako element jakości finansów publicznych. Management and Business Administration. Central Europe, Iss. 2(121).

12. Franek, S. (2013). Reguły fiskalne w przemianach instytucjonalnych finansów publicznych. Finanse, Rynki finansowe, Ubezpieczenia, No. 39, Zeszyty Naukowe Uniwersytetu Szczecińskiego, No. 646.

13. Kopits, G., Symanski, S. (1998). Fiscal Policy rules. IMF Occasional Paper, No. 162.

14. Lotko, E., Zawadzka-Pąk, U.K. (2016). Problemy terminologiczne i definicyjne deficytu u długu w polskim i unijnym prawie finansów publicznych. Prawo Budżetowe Państwa i Samorządu, No. 2(4). Retrieved from: https://dx.doi.org/10.12775/PBPS.2016.009 [accessed: 15.09.2018].

15. Marchewka-Bartkowiak, K. (2012). Reguły fiskalne w warunkach kryzysu finansów publicznych. Ekonomia i Prawo, Quaterly, Vol. X, No. 3.

16. Moździerz, A. (2009). Nierównowaga finansów publicznych. Warszawa: PWE.

17. Owsiak, S. (2013). Dylematy interpretacyjne przy ocenie sytuacji finansowej państwa. Material from the 9th Congress of Polish Economists, Warszawa. 
18. Piwowarski, R. (2011). Reguły fiskalne oraz instrumenty nowego zarządzania publicznego jako narzędzia przejrzystej polityki fiskalnej. Studia Ekonomiczne, No. 3 (LXX).

19. Pomorski, P. (2014). Państwowy dług publiczny. In: P. Smoleń. (Ed.). Ustawa o finansach publicznych. Komentarz. Warszawa: Wydawnictwo C.H. Beck.

20. Postuła, M. (2011). Reguły fiskalne na świecie i w Polsce. $M B A$, No. 5/2011.

21. Premchard, A. (1999). Public Financial Accountability. In: Asian Review of Public Administration, XI (2).

22. Redo, M., Wójtowicz, K., Ciak, J.M. (2018). Bezpieczeństwo Finansów Publicznych. Warszawa: CeDeWu.

23. Słownik Współczesnego Języka Polskiego (1998). Vol. I, Warszawa: Przegląd Reader’s Digest.

24. Wajda-Lichy, M. (2006). Reguły a przejrzystość polityki fiskalnej. In: D. Kopycińska (Ed.), Regulacyjna rola państwa we współczesnej gospodarce. Szczecin: Printgroup.

25. Wójtowicz, K. (2011). Problem konstrukcji optymalnej reguły fiskalnej w warunkach kryzysu finansowego. Zeszyty Naukowe PTE, No. 10. 